\title{
IDENTIFIKASI METABOLIT SEKUNDER DAN UJI AKTIVITAS ANTIBAKTERI ISOLAT JAMUR ENDOFIT DAUN BELUNTAS (PLUCHEA INDICA (L.) LESS.)
}

\author{
Jessie Elviasari, Rolan Rusli, Adam M. Ramadhan \\ Laboratorium Penelitian dan Pengembangan FARMAKA TROPIS, Fakultas \\ Farmasi, Universitas Mulawarman, Samarinda, Kalimantan Timur \\ email: jessie_viasari@yahoo.com
}

\begin{abstract}
Over-exploitation for obtaining secondary metabolites from natural resources can cause the extinction of natural resources. The right solution is through the development of endophytic microbes as producers of secondary metabolites. Endophytic fungi could potentially produce the secondary metabolites the same as its host. One of the medicinal plants that potential as antibacterial is Pluchea indica (L.) Less, thus allowing the endophytic fungi isolated from Pluchea indica (L.) Less also has the antibacterial activity. The purpose of this study were to identification of secondary metabolites, and activity test of secondary metabolites produced by fungi endophyte as an antibacterial of endophytic fungi of Pluchea indica (L.) Less. Antibacterial activity test was using agar diffusion method and paper discs. Bacteria of test used were Staphylococcus aureus, Staphylococcus epidermidis, Escherichia coli, and Pseudomonas aeruginosa. The results of the study were found three isolates of endophytic fungi that grow on the leaves of Pluchea indica (L.) Less. viz. White endophytic fungi isolated, black endophytic fungi isolated 1 and black endophytic fungi isolated 2. The content of secondary metabolites from three isolates of endophytic fungi was phenols and alkaloids. Only black endophytic fungi isolated 2 was inhibited bacterial activity test with inhibition on Staphylococcus aureus, Staphylococcus epidermidis, Escherichia coli, and Pseudomonas aeruginosa was $5.474 \mathrm{~mm}, 5.206 \mathrm{~mm} 5.057 \mathrm{~mm}$, and $5.107 \mathrm{~mm}$, respectively.
\end{abstract}

Keywords: Endophytic fungi, antibacterial, secondary metabolit, Pluchea indica (L.) Less.

\begin{abstract}
ABSTRAK
Eksploitasi berlebihan untuk memperoleh metabolit sekunder dari bahan alam dapat menyebabkan kepunahan bahan alam tersebut, sehingga solusi yang tepat yaitu melalui pengembangan mikroba endofit sebagai penghasil metabolit sekunder. Jamur endofit berpotensi menghasilkan metabolit sekunder seperti inangnya. Daun beluntas (Pluchea indica (L.) Less.) memiliki aktivitas sebagai antibakteri, maka diduga dapat pula isolat jamur endofit yang terdapat dalam jaringan daun beluntas menghasilkan metabolit sekunder yang sama dengan
\end{abstract}


tanaman inangnya sehingga memungkinkan memiliki efek yang sama pula dengan tanaman inangnya. Tujuan penelitian ini adalah untuk mengidentifikasi golongan metabolit sekunder dan menguji aktivitas antibakteri metabolit sekunder yang dihasilkan isolat jamur endofit dari daun beluntas. Pengujian aktivitas sebagai antibakteri menggunakan metode difusi agar dengan menggunakan kertas cakram (paper disc). Bakteri uji yang digunakan adalah Staphylococcus aureus, Staphylococcus epidermidis, Escherichia coli dan Pseudomonas aeruginosa. Dari hasil isolasi jamur endofit diperoleh tiga isolat yaitu isolat jamur endofit putih, isolat jamur endofit hitam 1 dan isolat jamur endofit hitam 2 yang ketiganya memiliki kandungan metabolit sekunder yaitu fenol dan alkaloid. Dari ketiga isolat jamur endofit hanya satu jamur yang memiliki aktivitas menghambat pertumbuhan keempat bakteri uji tersebut yaitu ekstrak isolat jamur endofit hitam 2. Aktivitas antibakteri ekstrak isolat jamur endofit hitam 2 ditunjukkan dengan adanya daya hambat pada Staphylococcus aureus, Staphylococcus epidermidis, Escherichia coli dan Pseudomonas aeruginosa, dengan daya hambat berturutturut sebesar 5,474 mm, 5,206 mm, 5,057 mm, dan 5,107 mm.

Kata kunci : Jamur endofit, antibakteri, metabolit sekunder, beluntas (Pluchea indica (L.) Less.)

\section{PENDAHULUAN}

Salah satu sumber penghasil senyawa bioaktif yang berasal dari mikroba adalah mikroba endofit. Mikroba endofit merupakan mikroorganisme yang tumbuh dalam jaringan tumbuhan, terdapat pada jaringan akar, batang, dan daun pada tanaman. Beberapa mikroba endofit dapat menghasilkan senyawa bioaktif sebagai senyawa metabolit sekunder yang memiliki daya antimikroba, antimalaria, antikanker, dan sebagainya [1]. Hal ini karena mikroba merupakan suatu organisme yang mudah untuk ditumbuhkan, memiliki siklus hidup yang pendek, dan dapat menghasilkan jumlah senyawa bioaktif dalam jumlah besar dengan metode fermentasi [2].

Berdasarkan hasil penelitian kami sebelumnya diperoleh isolat jamur endofit sebanyak 3 isolaat yaitu isolat jamur endofit putih, isolat jamur endofit hitam 1 dan isolat jamur endofit hitam 2 [3]. Dari ketiga isolat ini diharapkan memiliki kandungan metabolit sekunder yang sama dengan inangnya yaitu daun beluntas, serta memiliki aktivitas yang sama pula, yaitu memiliki aktivitas antibakteri [4]. Berdasarkan hal tersebut, maka dilakukan penelitian penentuan kandungan metabolit sekunder dan pengujian aktivitas antibakteri.

\section{METODE PENELITIAN}

\section{Bahan}

Bahan yang diteliti adalah daun beluntas (Pluchea indica (L.) Less). Medium yang digunakan adalah medium Nutrient Agar/NA (Merck, 105450), Potato Dextrose Broth/PDB (Difco, 254920), $\mathrm{NaCl}$ $0,9 \%$ sebagai pensuspensi bakteri dan air suling sebagai pelarut ekstrak. Pelarut yang digunakan untuk proses ekstraksi yaitu metanol. 
Pereaksi yang digunakan untuk mengidentifikasi golongan metabolit sekunder yaitu dragendroff, $\mathrm{FeCl}_{3}$ $1 \%, \mathrm{HCl} 2 \%, \mathrm{HCl} 10 \%, \mathrm{HCl}$ pekat, $\mathrm{K}_{4} \mathrm{Fe}(\mathrm{CN})_{6}$, mayer dan pita $\mathrm{Mg}$. Bakteri uji yang digunakan adalah Escherichia coli, Pseudomonas aeruginosa, Staphylococcus aureus dan Staphylococcus aureus.

\section{Peralatan}

Peralatan yang digunakan dalam penelitian ini antara lain timbangan analitik, cawan porselin, autoklaf, inkubator, cawan petri, erlenmeyer, gelas kimia, spoit injeksi, wadah maserasi, hot plate, Laminar Air Flow, shaker, oven, waterbath, lemari pendingin dan alat penunjang lainnya.

\section{Prosedur Penelitian}

Sebelum dilakukan pembenihan dilakukan isolasi jamur isolasi jamur endofit yang prosedur dan hasilnya dapat dilihat pada artikel kami sebelumnya [Elviasari, 2015].

a. Pembenihan Isolat Jamur Endofit

Masing-masing isolat jamur endofit yang telah murni masingmasing selanjutnya akan diinokulasikan dalam labu Erlenmeyer yang berisi medium PDB (Potato Dextrose Broth) sebanyak 50 $\mathrm{mL}$ dan diinkubasi selama 3-5 hari pada suhu $25^{\circ} \mathrm{C}$.

b. Produksi Metabolit Sekunder
Isolat Jamur Endofit
Untuk memperoleh metabolit sekunder dari isolat jamur endofit, maka dari hasil pembenihan diambil $5 \mathrm{~mL}$ dan diinokulasikan dalam labu Erlenmeyer berisi medium PDB sebanyak $250 \mathrm{~mL}$. Selanjutnya diinkubasi dengan penggoncangan menggunakan shaker dengan kecepatan 150 rpm selama 14 hari. Hasil inkubasi disaring untuk memperoleh miselium jamur. Miselium jamur dioven terlebih dahulu dengan suhu $50{ }^{\circ} \mathrm{C}$ hingga jamur kering. Jamur yang telah kering selanjutnya diekstraksi menggunakan metode maserasi yaitu dengan cara merendam seluruh bagian jamur dengan pelarut metanol selama 2 hari. Dari hasil ekstraksi kemudian disaring dan diperoleh ekstrak cair hasil maserasi yang akan di uapkan di atas waterbath hingga diperoleh ekstrak kering. Ekstrak inilah yang selanjutnya akan diidentifikasi golongan metabolit sekunder.

\section{c. Identifikasi Golongan Metabolit Sekunder \\ 1). Uji alkaloid \\ Sejumlah sampel} ditambahkan 2,5 $\mathrm{mL} \quad \mathrm{HCl} 2 \%$. Pengujian menggunakan 2 pereaksi yaitu pereaksi Dragendroff dan pereaksi Mayer. Adanya golongan senyawa alkaloid terbentuknya endapan jingga pada pereaksi Dragendroff atau endapan putih kekuningan pada pereaksi Mayer.

2). Uji Fenol

Sejumlah sampel ditambahkan 3 tetes $\mathrm{FeCl}_{3} 1 \%$ dan 3 tetes $\mathrm{K}_{4} \mathrm{Fe}(\mathrm{CN})_{6}$. Jika larutan berwarna biru atau hitam menandakan adanya golongan senyawa fenol.

3). Uji Flavonoid

Sejumlah

sampel ditambahkan pita $\mathrm{Mg}$ dan 5 tetes $\mathrm{HCl}$ pekat, kemudian dipanaskan. Jika larutan berwarna merah atau jingga 
menandakan adanya golongan flavonoid.

\section{4). Uji Saponin}

Sejumlah sampel ditambahkan aquadest, kemudian dikocok. Jika terbentuk buih, didiamkan selama 15 menit. Selanjutnya ditambahkan $\mathrm{HCl} 10 \%$ dan dikocok. Jika terdapat senyawa golongan saponin maka hasil positif bila buih stabil setelah pengocokan.

5). Uji Tanin

Sejumlah sampel ditambahkan 5 tetes $\mathrm{FeCl}_{3}$ 1\%. Jika larutan berwarna biru atau hitam menandakan adanya golongan senyawa tanin.

\section{d. Pengujian Aktivitas \\ Antibakteri \\ Biakkan murni bakteri hasil} inokulasi pada agar miring disuspensikan dengan menambahkan $\mathrm{NaCl} \quad 0,9 \%$ hingga diperoleh konsentrasi 1:40. Sebanyak 0,02 mL suspensi bakteri 1:40 dicampurkan dengan medium NA steril dituang ke dalam cawan petri kemudian dihomogenkan, selanjutnya ditunggu hingga medium memadat. Uji ini dilakukan menggunakan paper disc yang terbuat dari kertas saring Whatman. Paper disc yang telah disterilkan direndam dalam larutan ekstrak jamur endofit dan air suling sebagai kontrol negatif. Diambil paper disc kemudian diletakkan di atas medium uji yang telah memadat. Diinkubasi pada suhu $37{ }^{\circ} \mathrm{C}$ selama 24 jam. Jika memiliki aktivitas sebagai antibakteri maka akan ditunjukkan dengan terbentuknya zona bunuh atau zona hambat di sekitar paper disc. Selanjutnya diamati zona hambat yang terbentuk dan dilakukan pengukuran daerah hambatan dengan menggunakan mikrometer sekrup.

\section{HASIL DAN PEMBAHASAN}

Identifikasi Golongan
Metabolit Sekunder Isolat
Jamur Endofit
Hasil isolasi jamur endofit daun beluntas diperoleh tiga isolat yaitu isolat jamur endofit putih, yaitu isolat jamur endofit hitam 1 dan yaitu isolat jamur endofit hitam 2 [Elviasari, 2015]. Pengujian identifikasi golongan metabolit sekunder ketiga ekstrak isolat jamur endofit ini dilakukan secara kualitatif. Hasil identifikasi golongan metabolit sekunder ekstrak metanol seperti terangkum pada Tabel 1.

Tabel 1. Hasil identifikasi golongan metabolit sekunder Isolat Jamur Endofit

\begin{tabular}{cccc}
\hline \multirow{2}{*}{ Metabolit Sekunder } & \multicolumn{4}{c}{ Kode Ekstrak } \\
\cline { 2 - 4 } & $\begin{array}{c}\text { Isolat Jamur } \\
\text { Endofit Putih }\end{array}$ & $\begin{array}{c}\text { Isolat Jamur } \\
\text { Endofit Hitam 1 }\end{array}$ & $\begin{array}{c}\text { Isolat Jamur } \\
\text { Endofit Hitam2 }\end{array}$ \\
\hline Alkaloid & + & + & + \\
Fenol & + & + & + \\
Flavonoid & - & - & - \\
Saponin & - & - & - \\
Tanin & - & - & Tidak \\
\hline Keterangangandung \\
golongan senyawa
\end{tabular}


Berdasarkan tabel 1 ketiga ekstrak isolat jamur endofit memiliki metabolit sekunder yang sama. Pada uji identifikasi golongan alkaloid menunjukkan hasil positif yaitu pada pereaksi Dragendroff terbentuk endapan jingga. Pada uji identifikasi golongan fenol menunjukkan hasil positif yaitu larutan berwarna biru. Pada uji identifikasi golongan flavonoid menunjukkan hasil negatif karena larutan tidak berwarna merah atau jingga. Pada uji identifikasi golongan saponin menunjukkan hasil negatif karena tidak terbentuk buih atau busa yang stabil setelah pengocokan. Pada uji identifikasi golongan tanin menunjukkan hasil negatif karena larutan tidak berwarna biru atau hitam. Pada ekstrak isolat jamur endofit putih, ekstrak isolat jamur endofit hitam 1 dan ekstrak isolat jamur endofit hitam 2 memiliki metabolit sekunder alkaloid dan fenol, hal ini sesuai dengan [5] bahwa jamur endofit juga memiliki metabolit sekunder yang sama dengan tanaman inangnya yaitu daun beluntas mengandung golongan senyawa alkaloid dan fenol.

\section{b. Pengujian Aktivitas Antibakteri \\ Pengujian aktivitas} antibakteri ketiga ekstrak isolat jamur endofit terhadap bakteri Escherichia coli, Pseudomonas aeruginosa, Staphylococcus aureus dan Staphylococcus aureus. Air suling sebagai kontrol negatif yaitu pelarut yang digunakan untuk melarutkan ekstrak. Hasil pengujian aktivitas berupa zona hambat dapat dilihat pada Gambar 1 dan data nilai zona hambat disajikan pada Tabel 2.

Tabel 2. Data Aktivitas Antibakteri Ekstrak Isolat Jamur Endofit dari Daun Beluntas

\begin{tabular}{ccccc}
\hline \multirow{2}{*}{$\begin{array}{c}\text { Isolat Jamur } \\
\text { Endofit }\end{array}$} & \multicolumn{4}{c}{ Rerata Diameter Zona Hambat (mm) } \\
\cline { 2 - 5 } & $\begin{array}{c}\text { Staphylococcus } \\
\text { aureus }\end{array}$ & $\begin{array}{c}\text { Staphylococcus } \\
\text { epidermidis }\end{array}$ & $\begin{array}{c}\text { Escherichia } \\
\text { coli }\end{array}$ & $\begin{array}{c}\text { Pseudomonas } \\
\text { aeruginosa }\end{array}$ \\
\hline IJEP & - & - & - & - \\
$\mathrm{IJEH}_{1}$ & - & - & - & - \\
$\mathrm{IJEH}_{2}$ & 5,474 & 5,206 & 5,057 & 5,107 \\
Air Suling & - & - & - & - \\
\hline
\end{tabular}

Keterangan :

IJEP = Isolat Jamur Endofit Putih,

$\mathrm{IJEH}_{1} \quad=$ Isolat Jamur Endofit Hitam 1,

$\mathrm{IJEH}_{2} \quad$ = Isolat Jamur Endofit Hitam 2. 


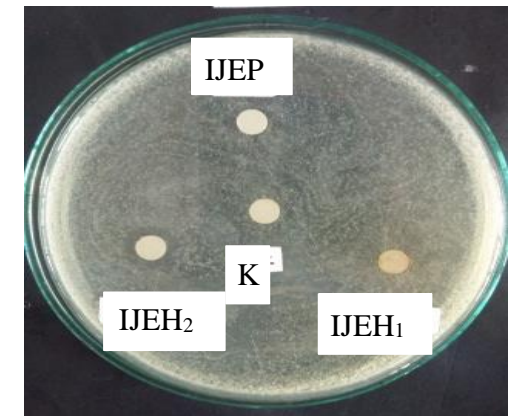

a. Staphylococcus aureus

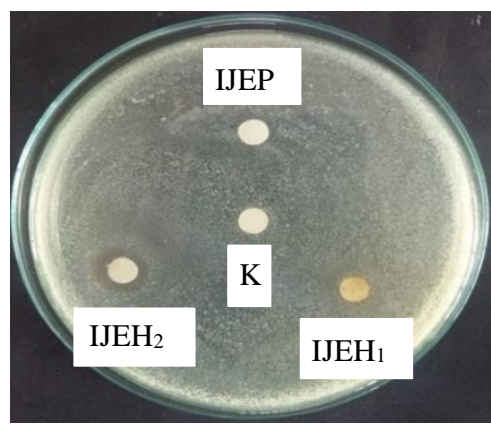

c. Escherichia coli

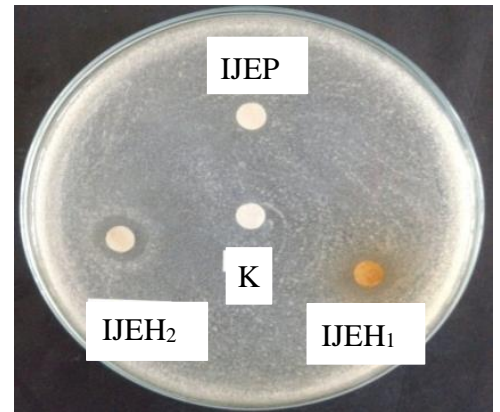

b. Staphylococcus epidermidis

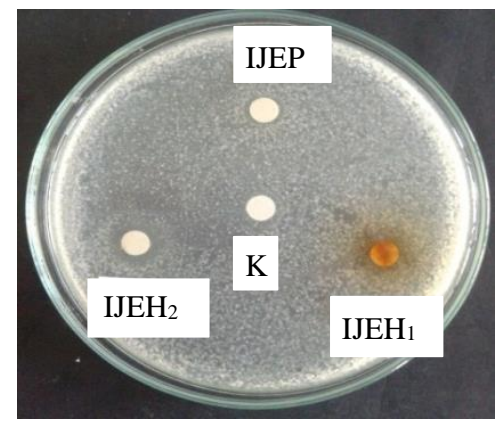

d. Pseudomonas aeruginosa

Gambar 1. Hasil Uji Aktivitas Antibakteri Isolat Jamur Endofit dari Daun Beluntas. $\mathrm{K}=$ Kontrol negatif, IJEP = Isolat Jamur Endofit Putih, $\mathrm{IJEH}_{1}=$ Isolat Jamur Endofit Hitam 1, IJEH $2=$ Isolat Jamur Endofit Hitam 2.

Gambar 1 dan Tabel 2 menunjukkan bahwa dari ketiga ekstrak isolat jamur endofit hanya satu ekstrak isolat jamur endofit yang memiliki aktivitas antibakteri yaitu ekstrak isolat jamur endofit hitam 2 yang ditandai dengan adanya zona hambat di sekitar paper disc. Pada kontrol negatif (air suling) tidak terbentuk zona hambat dan bunuh disekitar paper dis, sehingga dapat disimpulkan bahwa aktivitas antibakteri berasal dari ekstrak bukan dari pelarut yang digunakan untuk melarutkan ekstrak. Pada ekstrak isolat jamur endofit puih dan hitam 1 tidak memiliki aktivitas tetapi memiliki golongan metabolit sekunder yang sama dengan ekstrak isolat jamur endofit hitam 2 yaitu alkaloid dan fenol.

Berdasarkan hal tersebut diduga bahwa metabolit sekunder yang dihasilkan memang merupakan metabolit sekunder yang memiliki golongan yang sama, namun diduga memiliki struktur kimia yang berbeda, sehingga perlu dilakukan penelitian lebih lanjut berupa isolasi senyawa metabolit sekunder yang dihasilkan sehingga dapat ditentukan strukturnya sehingga senyawa metabolit sekunder yang aktif 
sebagai antibakteri dapat ditentukan secara tepat.

Hal ini kemungkinan karena kesamaan golongan metabolit sekunder bukan berarti harus memiliki aktivitas yang sama. Dalam satu golongan senyawa memiliki banyak jenis bahkan turunan, sehingga sangat memungkinkan golongan senyawa pada ekstrak isolat jamur endofit hitam 2 memiliki aktivitas antibakteri sedangkan pada golongan senyawa ekstrak isolat jamur endofit putih dan ekstrak isolat jamur endofit hitam 1 tidak memiliki aktivitas antibakteri. Selain itu kemungkinan juga dapat disebabkan karena konsentrasi senyawa yang memiliki aktivitas sebagai antibakteri pada ekstrak isolat jamur endofit putih dan ekstrak isolat jamur endofit hitam 1 terlalu kecil atau medium yang digunakan saat isolasi tidak memenuhi nutrisi yang diperlukan oleh jamur endofit untuk menghasilkan metabolit sekunder yang beraktivitas sebagai antibakteri.

\section{KESIMPULAN}

Hasil identifikasi metabolit sekunder ekstrak isolat jamur endofit putih, isolat jamur endofit hitam 1 dan isolat jamur endofit hitam 2 yang memiliki metabolit sekunder alkaloid dan fenol. Dari ketiga isolat jamur endofit hanya satu jamur yang memiliki aktivitas menghambat pertumbuhan keempat bakteri uji tersebut yaitu ekstrak isolat jamur endofit hitam 2.

\section{DAFTAR PUSTAKA}

1. Strobel, G. A., and B. Daisy. 2003. Bioprospecting for Microbial Endhophytes and Their Natural Products. Microbiology and Molecular Biology Review.67. (4). 419502.

2. Agusta, Andria. 2009. Biologi dan Kimia Jamur Endofit. ITB. Bandung.

3. Elviasari, Jessie, Rolan Rusli dan Adam M. Ramadhan. 2015. Isolasi Jamur Endofit Daun Beluntas (Pluchea indica (L.) Less.). Jurnal Sains dan Kesehatan. 1. (3). 126-130.

4. Sugijanto, N. E., G. Indrayanto, N. C. Zaini. 2004. Isolasi dan Determinasi Berbagai Jamur Endofit dari Tanaman Aglaia elliptica, Aglaia eusideroxylon, Aglaia odorata dan Aglaia odoratissima. Jurnal Penelitian Medika Eksakta.5. (2). 49-60.

5. Nurhalimah, Hanny, Novita Wijayanti, dan Tri Dewanti Widyaningsih. 2015. Efek Antidiare Ekstrak Daun Beluntas (Pluchea Indica L.) Terhadap Mencit Jantan Yang Diinduksi Bakteri Salmonella Thypimurium. Jurnal Pangan dan Agroindustri. III. (3). 1083-1094 